${ }^{\odot}$ Entomologica Fennica. 20 September 1996

\title{
New faunistic records of threatened saproxylic Coleoptera, Diptera, Heteroptera, Homoptera and Lepidoptera from the Republic of Karelia, Russia
}

\author{
Juha Siitonen, Petri Martikainen, Lauri Kaila, Ilpo Mannerkoski, Pertti Rassi, \& Ilpo Rutanen
}

Siitonen, J., Martikainen, P., Kaila, L., Mannerkoski, I., Rassi, P. \& Rutanen, I. 1996: New faunistic records of threatened saproxylic Coleoptera, Diptera, Heteroptera, Homoptera and Lepidoptera from the Republic of Karelia, Russia. - Entomol. Fennica 7:69-76.

Saproxylic insects were collected during fifteen expeditions to the Republic of Karelia in summers 1991-94. A total of 63 species ( 48 beetles, 15 others) included in the Finnish red data book are reported. Fourteen species of Coleoptera and Aradus ribauti Wagner are reported as new for Karelia. Notes on the biology of e.g. Hylochares cruentatus (Gyllenhal), Rhizophagus puncticollis Sahlberg, Cis fissicomis Mellié, Sulcacis bidentulus (Rosenhauer) and Leptura thoracica Creutzer are given. The number of threatened species found is striking considering the short period of time spent collecting in the field. We ascribe this to the management history of forests in Karelia, especially to the large amount of decaying wood in managed forests even. The forests in Karelia will be of crucial importance in preserving biodiversity and the last viable populations of numerous species that have disappeared in other parts of Fennoscandia.

Juha Siitonen, Finnish Forest Research Institute, P.O. Box 18, FIN-01301 Vantaa, Finland

Petri Martikainen, Department of Ecology and Systematics, Division of Population Biology, P.O. Box 17 (Arkadiankatu 7), FIN-00014 University of Helsinki, Finland

Lauri Kaila, Zoological Museum, P.O. Box 17 (P. Rautatiekatu 13), FIN-00014 University of Helsinki, Finland

Ilpo Mannerkoski \& Ilpo Rutanen, Finnish Environment Agency, P.O. Box 140, FIN-00251 Helsinki, Finland

Pertti Rassi, Ministry of the Environment, P.O. Box 399, FIN-00121 Helsinki, Finland

Received 2 March 1994, accepted 14 June 1996

\section{Introduction}

The present study is a summary of new faunistic records and notes on the biology of saproxylic beetles and other insects collected in the Republic of Karelia. The material was collected by the authors JS, PM and LK during twelve expeditions from May to September in 1991-94, by IM, PR and IR during the summer excursion of the Entomological Society of Finland in July 1992, by PR 


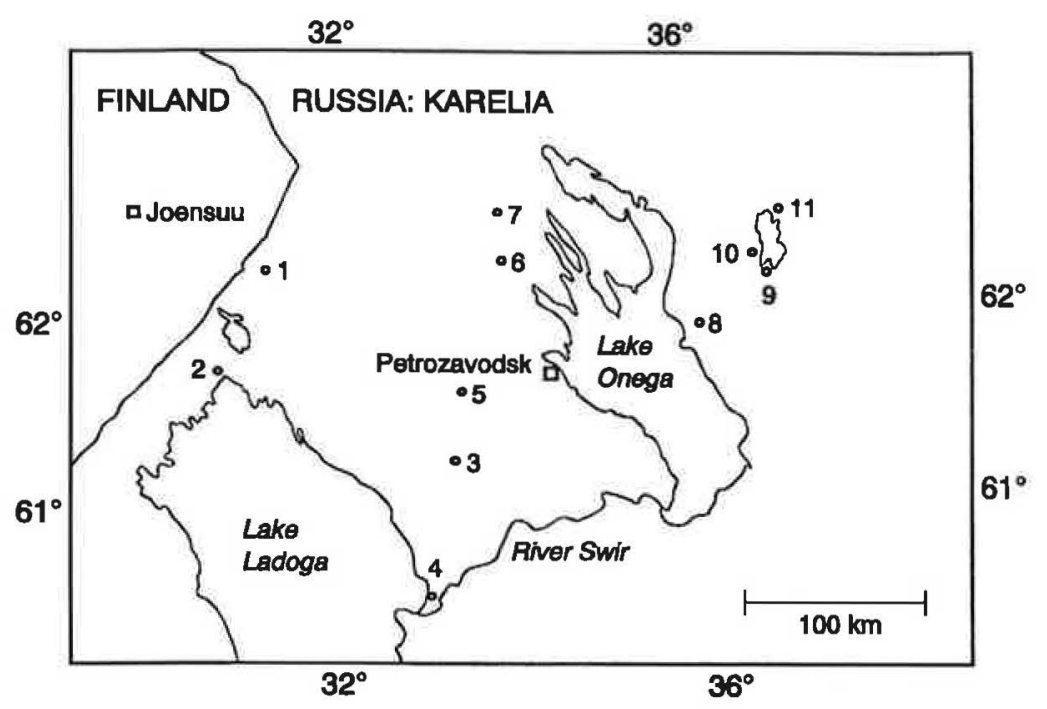

Fig. 1. The most important collecting localities in the Republic of Karelia: $1=K b$ : Korpiselkä-Tolvajärvi, $2=K l$ : Sortavala, 3 = Kol: Kaskesniemi, 4 = Kol: Gumbaritsa, 5 = Kol: Kotkatjärvi, $6=$ Kon: Kivach nature reserve, $7=$ Kon: Tiutia, $8=K$ ton: Avdejevo, $9=$ Kton: Kuganavolok, $10=$ Kton: Vodlozero, 11 = Kton: Ilexa River and Novguda. See the text for collecting dates and habitat descriptions. in Vodlozero, river Ilexa in July 1992 and by JS in Vodlozero, Novguda in August-September 1994.

\section{Study area, collecting methods and sites}

A number of localities were visited in the biogeographical provinces $\mathrm{Kb}, \mathrm{Kl}, \mathrm{Kol}, \mathrm{Kon}$ and Kton (anon. 1938, 1944). (Kol: Gumbaritsa administratively belongs to the Leningrad district.) The collecting methods used were hand-picking from trunks, polyporous fungi and flowers, peeling bark and excavating the soft parts of decaying trunks, sifting and sweep-netting. The most important collecting sites were the following (Fig. 1):

(1) $K b$ : Korpiselkä, Tolvajärvi, several dates from May till September in 1992-94, JS, PM, LK and Pekka Punttila leg. Mostly old spruce-dominated, paludified forests, but also young and pine-dominated forests. Two small forest fire areas burnt one and about three years earlier were also visited.

(2) Kl: Sortavala, 26.7.93, JS, PM and LK leg. A large area of luxuriant mixed forest which had been burnt and thereafter logged about two years earlier. Some burnt spruces, birches, aspens etc. had been left on the edges of the burnt area.

(3) Kol: Kaskesniemi, 11.-12.7.92, IM, PR and IR leg. Mostly spruce-dominated, partly swampy forest. Birch was abundant as a mixed tree species, and trunks with polyporous fungi were common.

(4) Kol: Gumbaritsa, north of river Svir, 8.11.7.92, IM, PR, IR and Risto livarinen leg. A luxuriant virgin forest dominated by spruce with large aspens. Dead standing and fallen aspens were abundant, some of them cut down by beavers.

(5) Kol: Kotkatjärvi, about $90 \mathrm{~km}$ southwest of Petrozavodsk, 14.7.92 and 28.7.93 JS, PM and LK leg. Dead and weakened aspens along the roadside.

(6) Kon: Kivach Nature Reserve, 26.-28.7.93, JS, PM, LK and Andrei Humala leg. Luxuriant virgin forests, mostly sprucedominated, with plenty of large dead aspens. We collected mostly from dead aspens that often had a diameter at breast height of 80$90 \mathrm{~cm}$.

(7) Kon: Tiutia, about $30 \mathrm{~km}$ south of Karhumäki, 15. and 18.7.92, JS, PM and Andrei Humala leg. A residual stand with birch, aspen and pine, logged and burnt about two years earlier.

(8) Kton: Avdejevo, 15. and 18.7.92, JS and PM leg. Large dead aspens along the roadside.

(9) Kton: Kuganavolok, 17.7.92, JS and PM leg. We primarily collected in a large clearcut area logged about ten years earlier. All the aspens had been left in the area, creating 
a continuum of living, weakened and dead standing and fallen trees in different stages of decay.

(10) Kton: Vodlozero SW shores, 15.-17.7.92, JS and PM leg. Mostly old sprucedominated, swampy forests with dead aspens.

(11) Kton: Vodlozersky National Park, Ilexa river, 21.-23.7.92, PR leg., Vodlozersky National Park, Novguda, 23.8.-3.9.94, JS leg. Spruce-dominated flood plain forests. In Novguda, spruce-dominated forests and mires, and a sub-dry pine forest.

\section{Species found}

A total of 63 saproxylic species included in the Finnish red data book (Rassi et al. 1992) were recorded (Table 2). Thirteen saproxylic beetle species with at the most one record in Finland during the last 35 years (after 1960) were found. Fourteen species of Coleoptera new for the Karelian Republic according to Silfverberg (1992) are reported (Table 1). Aradus ribauti Wagner (Hom., Aradidae) is a species new for Fennoscandia. Below, notes on the occurrence and biology are given for some poorly known species.

\subsection{Coleoptera}

\section{Staphylinidae}

Gyrophaena nitidula (Gyllenhal). Kon: Kivach, 27.7.93, 2 ex. On a soft agaric growing on Salix caprea. The sample of Gyrophaena spp. from the fungus included the following other species: pulchella Heer 1 ex., affinis Mann, 2 ex., poweri Crotch 2 ex., fasciata (Marsham) 260 ex. and joyi Wend. 2 ex. This species has previously been found only in southern Sweden (provinces $S k$ and $S m$ ) in Fennoscandia (Palm 1968, Lundberg 1986).

\section{Eucnemidae}

Hylochares cruentatus (Gyllenhal). Kton: Avdejevo, 15.7.92, 10 ex. Kton: Kuganavolok, 17.7.92, abundant. We found this species at three different loca- tions on almost identical aspens. The trees stood in spruce dominated forests, two in grass-herb Aconitum type forest edges and one in an OxalisMyrtillus type forest (Cajander 1949). They were dead, giant aspens with a diameter at breast height of almost one meter. The upper bole was barkless and the base was covered with completely loose bark. The surface wood was soft, rather dry and heavily white-decayed. At the two first sites, three and seven individuals of $H$. cruentatus were caught traversing the bark. At the third site, we removed pieces of bark on the base and discovered that several hundred individuals were just emerging from the surface wood. The only other insects found under the bark were two specimens of Aradus truncatus Fieber.

Kon: Kivach, 26.-28.7.93, 14 ex. Besides the living specimens, we found galleries and fragments of adults on about fifteen aspens in different locations. All the trees were large, dead standing trunks with a sock of loose bark on the base. The surface wood was always rather dry and heavily whitedecayed. Adults of Ptilinus fuscus Geoff. were frequently found on the same trees. Besides the as-

Table 1. Coleoptera new to the republic of Karelia. The collecting localities are given according to Fig. 1 and the text.

\begin{tabular}{|c|c|}
\hline Family/species & Localities \\
\hline \multicolumn{2}{|l|}{ Staphylinidae } \\
\hline Gabrius splendidus (Gravenhorst) & 4 \\
\hline Lordithon exoletus(Erichson & 4 \\
\hline Sepedophilus constans(Fowler) & 4 \\
\hline Tachinus basalisErichson & 1 \\
\hline Gyrophaena nitidula(Gyllenhal) & 6 \\
\hline CyphahanseniPalm & 6 \\
\hline \multicolumn{2}{|l|}{ Pselaphidae } \\
\hline Batrisodes venustus (Reichenbach) & 7 \\
\hline \multicolumn{2}{|l|}{ Throscidae } \\
\hline Aulonothroscus laticollis(Rybinski) & 6 \\
\hline \multicolumn{2}{|l|}{ Buprestidae } \\
\hline Agrilus ater(L.) & 6 \\
\hline \multicolumn{2}{|l|}{ Cisidae } \\
\hline Cis glabratus Mellié & 1,6 \\
\hline Cis fissicomis Mellié & 4,11 \\
\hline EnnearthronpalmiLohse & 4 \\
\hline \multicolumn{2}{|l|}{ Cerambycidae } \\
\hline Anoploderalivida(F.) & 4,Kt:Salmi,Kot:Aunus \\
\hline \multicolumn{2}{|l|}{ Scolytidae } \\
\hline Orthotomicus longicollis (Gyllenhal) & 11 \\
\hline
\end{tabular}


Table 2. Red-listed saproxylic species collected in the Republic of Karelia during excursions in 1991-94. The status in southern Finland is given according to Rassi et al. (1992) and the unpublished corrections made thereafter: $\mathrm{D}=$ disappeared, $\mathrm{E}=$ endangered, $\mathrm{V}=$ vulnerable and $\mathrm{M}=$ in need of monitoring. Species recorded at the most once in Finland during the last thirty-five years $(1960-1995)$ are marked with an asterisk $\left(^{*}\right)$. The collecting localities are given in numbers according to Fig. 1 and the text.

\begin{tabular}{|c|c|c|c|c|c|}
\hline \multirow{2}{*}{$\begin{array}{l}\text { ORDER/Family/Species } \\
\text { COLEOPTERA }\end{array}$} & \multicolumn{2}{|c|}{ Status Localities } & \multirow{2}{*}{$\frac{\text { ORDER/Family/Species }}{\text { Upis ceramboides (L). }}$} & \multicolumn{2}{|c|}{ Status Localities } \\
\hline & & & & V & $1,3,6,8,9$ \\
\hline Trachypachidae & & & Corticeus longulus (Gyllenhal) & M & 11 \\
\hline Trachypachus zetterstectii (Gyllenhal) & V & 2 & C. fraxini (Kugelann) & $M$ & 11 \\
\hline Staphylinidae & & & Mordellidae & & \\
\hline Phymatura brevicollis (Kraatz) & V & 4, Kt:Salmi & Tomoxia bucephala Costa & $M$ & 7,10 \\
\hline Cyphea latiuscula Sjöberg & M & 11 & Melandryidae & & \\
\hline Pselaphidae & & & Dircaea quadriguttata (Paykull) & V & 6,9 \\
\hline Batrisodes venustus (Reichenbach) & $\mathrm{M}^{*}$ & 7 & Melandrya dubia (Schaller) & M & 1,11 \\
\hline Histeridae & & & Cerambycidae & & \\
\hline Acritus minutus(Herbst) & $\mathrm{V}^{*}$ & 7,9 & S. perforata (Pallas) & $M$ & $5,6,7,8$ \\
\hline Hololepta plana(Sulzer) & $E^{\star}$ & 5 & Tragosoma depsaritum (L.) & V & 1,10 \\
\hline Lucanidae & & & Evodinus borealis (Gyllenhai) V & 1 & \\
\hline Ceruchus chrysomelinus (Hochenwart) & V & $1,6,9,11$ & Acmaeops septentrionis (Thomson) & $E$ & 1 \\
\hline Elateridae & & & Leptura nigripes Degeer. & $\bar{V}$ & $4,8,10,11$ \\
\hline Lacon fasciatus $(L)$. & M & 1 & L thoracica Creutzer & $\mathrm{E}^{\star}$ & 4,6 \\
\hline Ampedus suecicus Palm & V & 9,11 & Monochamus unussovil(Fischerv. & & \\
\hline Eucnemidae & & & Waldheim) & V & 11 \\
\hline Hylochares cruentatus (Gyllenhal) & $D^{*}$ & $6,8,9,11$ & Anthribidae & & \\
\hline Rhacopus attenuatus(Mäklin) & $\mathrm{E}^{*}$ & 8 & Platyminus resinosus (Scopoli) & V & 2,7 \\
\hline Buprestidae & & & Curculionidae & & \\
\hline Dicerca furcata (Thunberg) & $E$ & 7 & Cossonus cylindricus Sahlberg & $E^{\star}$ & 6,11 \\
\hline Melanophila acuminata(Degeer) & $\bar{M}$ & 1,2 & Scolytidae & & \\
\hline Agrilus ater (L.) & $\mathrm{E}$ & 6 & Xylebons cryptographus (Ratzeburg) & $\mathrm{V}^{*}$ & $4,5,6$ \\
\hline Bostrichidae & & & Orthotomicus longicollis (Gyllenhai) & $\mathrm{V}^{*}$ & 11 \\
\hline Stephanopachys substriatus (Paykull) & $M$ & 1 & & & \\
\hline S. linearis (Kugelann) & M & 1 & $\begin{array}{l}\text { HETEROPTERA } \\
\text { Aradidae }\end{array}$ & & \\
\hline Trogositidae & & & & & \\
\hline Calitys scabra(Thunberg) & V & 1 & Aradus inuncatus Fieber & E & 6,9 \\
\hline Peltis grossa $(L)$. & $M$ & $1,4,6,7,8,9,10,11$ & Aradus crenaticollisF. Sahiberg & $\mathrm{M}$ & 7 \\
\hline Nitidulidae & & & Aradus betulinus Fallén & $M$ & 1 \\
\hline Cyllodes ater(Herbst) & $E^{*}$ & $3,6,9$ & Aradus pictus Bärensprung & M & 1 \\
\hline Rhizophagidae & & & HOMOPTERA & & \\
\hline Ahizophagus puncticollis Sahlberg & $D^{*}$ & $4,5,6$ & Achilidae & & \\
\hline Cucujidae & & & Cixidia confinis (Zetterstedt) & $M$ & 1,1 \\
\hline Cucujus cinnaberinus (Scopoli) & $E$ & 9 & Cixidia lanoonica (Zetterstedt) & $M$ & 1 \\
\hline Silvanus unidentatus (Olivier) & M & $2,6,7,9$ & & & \\
\hline Uleiota planata $(\mathrm{L})$ & $E^{*}$ & 5,9 & DIPTERA & & \\
\hline Erotylidae & & & Keroplatidae & & \\
\hline Triplaxnmipes (F.) & M & 1,6 & Keroplatus tipuloides Bosc & V & 6, Kt: Ruskeala \\
\hline Cerylonidae & & & Xylomyidae & & \\
\hline $\begin{array}{l}\text { Cerylon impressum Erichson } \\
\text { Cisidae }\end{array}$ & M & 11 & $\begin{array}{l}\text { Xylomya czekanowskï (Pleske) } \\
\text { (= Solva intempta) }\end{array}$ & $\mathrm{E}$ & $1,2,4,6,11$ \\
\hline Cis fissicomis Mellié & $M^{*}$ & 4,11 & Spilomyia diophthaima (L) & $M$ & see the text \\
\hline Sulcacis fronticomis (Panzer) & $\mathrm{M}$ & 3 & Temnostoma apifome (F.) & $M$ & see the text \\
\hline Wagaicis wagai(Wankowicz) & $\mathrm{V}^{*}$ & 6,11 & Temnostoma vespifome (L.) & $\mathrm{M}$ & see the text \\
\hline Mycetophagidae & & & Temnostoma bombylans (F.) & $M$ & see the text \\
\hline Mycetophagus quadripustulatus (L.) & M & 6 & & & \\
\hline Pythidae & & & LEPIDOPTERA & & \\
\hline Pytho kolwensis Sahlberg & $\mathrm{V}$ & 6,11 & Tineidae & & \\
\hline Boridae & & & Scardia boletella(F.) & $M$ & $1,6, K t$. Ruskeala \\
\hline Boros schneideri Panzer & $\mathrm{V}$ & 1,11 & Cossidae & & \\
\hline Cephaloidae & & & Lamellocossus terebra (Denis \& & & \\
\hline Scotodes annulatus Eschscholtz & v & Kt. Ruskeala & Schiffermüller) & M & $8,9,11$ \\
\hline Tenebrionidae & & & Sesiidae & & \\
\hline & & & Sesia bembeciformis (Hübner) & M & 6 \\
\hline
\end{tabular}


pens, we found $H$. cruentatus on a trunk of Salix caprea. Half of the c. $15 \mathrm{~cm}$ thick trunk was still alive, and the galleries were situated on the barkless, white decayed side of the trunk. A number of dead adults were found inside the surface wood.

Kton: Vodlozersky National Park, Novguda, 24.8., 26.8. and 1.9.1994. Larvae in rather hard and sound surface wood of two aspens in OxalisMyrtillus and Myrtillus type spruce forests. Fragments of adults under the bark of a heavily decayed aspen stump on a river bank.

Our observations agree well with the earlier notes on the biology of this species by E. Kangas and Y. Kangas (1944). They found $H$. cruentatus at five different locations in eastern Karelia, on large decaying aspens (diameter $50-80 \mathrm{~cm}$ ) in Aconitum type or Oxalis-Myrtillus type mixed forests. One individual was found on a broken Sorbus aucuparia, but according to the authors it was uncertain whether the species had actually developed in the tree.

There are two old records of $H$. cruentatus in Finland: $A b$ : Paimio, in the beginning of the 1800 's, and $A b$ : Mynämäki, probably in the $1920 \mathrm{~s}$ (Muona 1984). The species is classified as disappeared in Finland. According to our observations it is fairly easy to ascertain the presence of $H$. cruentatus. It seems to prefer large, white decayed aspens with completely loose bark and soft surface wood. Exit holes are round and strikingly variable in size. They can be very abundant and situated only one or two centimeters from each other in suitable places. White, powder-like frass often flows from the holes and accumulates under the bark. Larval galleries are distinctive, filled with frass, and run in all directions in the wood. Fragments of adults can usually be found under the bark at the base of the tree or inside hollow trunks.

Rhacopus attenuatus (Mäklin). Kton: Avdejevo, 15.7.92. One individual was found together with Hylochares cruentatus on a dead standing aspen. There is only one record of this species from Finland: $N$ : Helsinki, on a white-decayed linden (Muona 1984). The type specimens were collected in $K a$ :Kirjola (J. Muona, pers. comm.). Burakowski (1989) described the larva and biology of $R$. attenuatus in Bialowieza, Poland.

\section{Rhizophagidae}

Rhizophagus puncticollis Sahlberg. Kol: Gumbaritsa, 10.7.92, tens of specimens. Kon: Kivach, 26.-27.7.93, about 100 ex. Kol: Kotkatjärvi, 28.7.92, 2 ex. We found this species in numbers under the wet bark of recently dead standing or fallen aspens with galleries of Xyleborus cryptographus (Ratz.) and larvae of Saperda perforata (Pallas). Most of the individuals were found almost swimming in the fermented, brown and slimy phloem, in fallen trees primarily on the underside of the trunk. Rhizophagus cribratus Gyll. can often be found on aspen in slightly drier conditions, and some individuals were found together with $R$. puncticollis.

There is only one old record of $R$. puncticollis in Finland: $A b$ : Yläne in the beginning of the 1800 's (Rassi et al. 1985), and the biology of this species in Fennoscandia is so far completely unknown. $R$. puncticollis has been found in eastern Europe in Lithuania and the Bialowieza Primeval Forest in Poland through Beskids (Poland and Czech Republic) and the Carpathian Mountains (Slovakia) to Slovenia (Horion 1960, Burakowski et al. 1986). However, information about the biology is very scarce. The species has been found under bark near sap flows on Fagus (Burakowski et al. 1986) and on Fraxinus in galleries of Hylesinus crenatus Fabr. (Okolów 1970).

\section{Cucujidae}

Uleiota planata (L.). Kton: Kuganavolok, 17.7.92, 4 ex. Under loose and dry pieces of bark of a fallen aspen. We also observed four larvae on the same tree. Kol: Kotkatjärvi, 28.7.93, 2 ex. Under dry, tight bark of a standing, exposed aspen together with Hololepta plana (Sulzer). There are no records of this species during the past few decades either in Finland (Rassi et al. 1985) or in Sweden (Palm 1959, Lundberg 1978, 1984).

\section{Erotylidae}

Triplax rufipes (F.). Kl: Kaalamo, 25.7.93, 5 ex. Kon: Kivach, 26. and 27.7.93, 2 ex. Kb: Tolvajärvi, $29.7 .93,12 \mathrm{ex}$. All the individuals were found on Pleurotus pulmonarius (Fr.)Quél. (or other similar 
species) growing on birch or on aspen. Other species that we frequently found together with $T$. rufipes on Pleurotus include Lordithon trimaculatus (Payk.), Cyllodes ater (Herbst), Triplax aenea (Schaller), T. russica (L.), T. scutellaris Charp. and Mycetophagus quadripustulatus (L.).

\section{Cisidae}

Cis fissicornis Mellié. Kol: Gumbaritsa, 10.7.92,6 ex. Kton: Vodlozero, Novguda, 27.8.94, 5 ex. In Vodlozero, the specimens were found in fruiting bodies of Trametes ochracea (Pers.) Gilb. \& Ryvarden (= zonata) growing on a fallen aspen together with numerous Cis boleti (Scopoli) and Sulcacis affinis (Gyll.). In central Europe, C. fissicornis has been found on Trametes spp. (Johannes Reibnitz, pers. comm.).

Sulcacis bidentulus (Rosenhauer). Kton: Kuganavolok, 17.7.92, 3 ex. On resupinate polyporous fungi (probably Rigidoporus corticola (Fr.) Pouzar) growing under the bark of a fallen aspen. Gyrophaena angustata (Steph.) and Aradus ribauti Wagner nymphs were found in the same place. Kivach, 27.7.93, 1 ex. On a fallen aspen trunk with Rigidoporus corticola and Funalia (= Trametes) trogii (Berk.) Bond. \& Sing. (det. Reijo Penttilä). Two individuals emerged from $F$. trogii (which is an endangered species in Finland) taken into rearing together with about ten Sulcacis affinis (Gyll.).

Within Fennoscandia S. bidentulus is known only from Karelia (Silfverberg 1992). There are two records from Karelia onegensis (Kenjärvi 1942 and Jallahti 1943, Saalas 1948). At both locations the species was found on fallen aspen trunks on a Trametes species, probably hirsuta (Wulfen: Fr.) Pilát (which may easily be confused with $F$. trogii), together with $G$. angustata. In central Europe $S$. bidentulus lives mainly on Funalia trogii growing on sun-exposed Populus trunks (Johannes Reibnitz, pers. comm.).

Wagaicis wagai (Wankowicz). Kon: Kivach, 28.7.93. One specimen was found on an unidentified polypore growing inside the hollow base of an aspen together with Cis boleti (Scopoli). Kton: Ilexa river, 23.7.92. One specimen on Pleurotus pulmonarius (?) growing on a birch trunk in a dry pine forest. There is only one record of $W$. wagai from Finland (Muona 1985).

\section{Cerambycidae}

Leptura thoracica Creutzer. Kol: Gumbaritsa, 10.7.92. One dead specimen was found in its exit hole on a dead, c. $25 \mathrm{~cm}$ thick trunk of aspen, at a height of $1.5 \mathrm{~m}$. The trunk was partially covered with loose bark and standing in a spruce-dominated moist forest with luxuriant ground vegetation dominated by ferns. The surface of the trunk was quite soft, partly white-decayed. The following other species were observed in the same trunk: Ptilinus fuscus (Geoff.), Ennearthron palmi Lohse and Necydalis major (L.).

Kon: Kivach, 27.7.92. One female was found resting on a barkless aspen trunk. We found probable larval galleries and 4 larvae of this species on a fallen aspen. The trunk was about $50 \mathrm{~cm}$ thick, moist and covered with bark, laying in a sprucedominated moist forest. The larval tunnels occurred over the whole trunk. They primarily ran in a longitudional direction and were located in the soft white-decayed surface wood down to a depth of about 3-4cm, where the wood became harder.

There are four old records of $L$. thoracica in Finland from the 1800 's, and only one recent find from $N$ : Mäntsälä (a dead specimen in its pupal chamber, Rutanen \& Mannerkoski 1987). In addition, there is one old record from the Karelian Isthmus, probably collected in the 1920's (Kangas 1947).

\subsection{Heteroptera}

\section{Aradidae}

Aradus ribauti Wagner. Kton: Kuganavolok, 17.7.92, 2 adults and 4 nymphs. Under the bark of fallen aspens on resupinate polyporous fungi (probably Rigidoporus corticola (Fr.) Pouzar). The trunks were lying in a sunny place; only dry pieces of bark were left. This species was described by Wagner (1955) and the larva by Vásárhelyi (1978). The distribution area covers southern and middle Europe and European parts of Russia, east to western Siberia (Tobolsk) and north to the Leningrad 
and Vologda regions (C.-C. Coulianos, pers. comm.). According to the available data, A. ribauti is always found on Populus species.

\subsection{Diptera}

\section{Syrphidae}

Spilomyia diophthalma (L.), Temnostoma apiforme (F.) and Temnostoma vespiforme (L.). We observed these species at many different places along the roadsides during stops in $\mathrm{Kb}, \mathrm{Kl}, \mathrm{Kol}, \mathrm{Kon}$ and Kton. T. vespiforme was by far the most abundant species with tens of specimens seen. The species visited flowers of Filipendula ulmaria especially.

Temnostoma bombylans (F.). Kton: Kuganavolok, 17.7.92, 1 ex. Kl: Ruskeala, 26.7.93, 2 ex. Kon: Kontupohja, 27.7.93, 1 ex. Evidently the rarest species of these syrphids. The specimen in Kuganavolok was caught on a fresh aspen log, others in flowers.

\section{Conclusions}

The number of rare and threatened saproxylic species found in the Republic of Karelia (below: Karelia) within a relatively short time is striking. The abundance of these species in Karelia is obviously a consequence of the different management history of the forests in Karelia compared to other parts of Fennoscandia. This was pointed out by Kangas as early as 1947. At present, the main differences in the structure of forests between Finland and Karelia may be summarized as follows: The forests in Karelia have not been subjected to repeated thinnings, and decaying wood therefore usually occurs abundantly even in managed forests. Siitonen $\mathrm{et} \mathrm{al}$. (1995) found that the average amount of decaying wood in ordinary managed forests was almost tenfold in Karelia compared to Finland $\left(3,7 \mathrm{~m}^{3} /\right.$ ha and $28,7 \mathrm{~m}^{3} / \mathrm{ha}$, respectively). Owing to the absence of thinnings, the proportion of deciduous trees (e.g. aspen) is much higher in Karelia than in Finland. The continuous availability (in space and time) of large dead aspens has probably been essential for the survival of numerous species associated with aspen in Karelia (Siitonen \& Martikainen
1994). Forest fires have been frequent, and burnt areas of different ages are common in Karelia.

Many species that are classified as disappeared or endangered in Finland (e.g. Hylochares cruentatus (Gyllenhal), Cyllodes ater (Herbst) and Rhizophagus puncticollis Sahlberg) were found abundantly at several different locations indicating that they still have viable populations in Karelia. The forests in Karelia will be of crucial importance in conserving, preserving and, eventually, restoring biodiversity in Fennoscandia.

Acknowledgements. We would like to express our sincere gratitude to Evgenii Yakovlev, Andrei Humala, Alexey Polevoi, Viktor Kovalev, Mark Kosmenko and Oleg Tshervjakov for the excellent arrangements during the expeditions. We thank Jyrki Muona for commenting on the manuscript, Carl-Cedric Coulianos for the identification of Aradus ribauti and for providing literature, and Stig Lundberg for checking some Coleoptera specimens. Remigius Geiser, Jerzy Gutowski, Frank Köhler and Johannes Reibnitz kindly provided us with information about the biology of different species in central Europe. We thank John Derome for improving the language. The study was partly financed by the Tor and Maj Nessling Foundation.

\section{References}

Anon. 1938: A list of local names from the Finnish naturalscientific area. - Ann. Entomol. Fennici 2:128-144.

- 1944: Suomen ja Itä-Karjalan maakunta- ja paikannimistö. [Provincial and local names of Finland and eastern Karelia.] (In Finnish.) - Ann. Entomol. Fennici 10:141-144.

Burakowski, B., Mroczkowski, M. \& Stefanska, J. 1986. Katalog fauny Polski. Czesc XXIII, tom 12. Chraszcze Coleoptera. Cucujoidea, czesc 1. Warszawa: PWN, 266 pp.

Horion, A. 1960: Faunistik der mitteleuropäischen Käfer. Bd. VII: Clavicornia, 1. Teil (Sphaeritidae bis Phalacridae). Berlingen/Bodensee.

Kangas, E. 1947: Kovakuoriaisfaunamme erikoisuuksia luonnosuojelun kannalta. - Suomen Luonto 6:45-55.

Kangas, E. \& Kangas, J. 1944: Über die lebensweise und die larve von Xylophilus cruentatus Gyll. (Col., Eucnemidae). - Ann. Entomol. Fennici 10:7-16.

Lundberg, S. 1978: Skalbaggsarter som inte återfunnits i Sverige på lång tid - några tips (Coleoptera). — Entomol. Tidskr. 99:121-126.

- 1984: Bidrag till kännedom om svenska skalbaggar 22. - Entomol. Tidskr. 105:107-108.

- (ed.) 1986: Catalogus Coleopterorum Sueciae. Entomologiska Föreningen i Stockholm och Naturhistoriska Riksmuseet, Stockholm. 
Muona, J. 1984: Contribution to the knowledge of Finnish false click-beetles (Coleoptera, Eucnemidae). - Notulae Entomol. 65:127-128.

- 1985: Additions and corrections to the Finnish list of Coleoptera. -- Notulae Entomol. 65:127-128.

Okolow, C. 1970: Hylesinus crenatus Fabr. the large ash bark beetle, its morphology, biology, enemies and economic importance. (In Polish with English summary.) - Folia Forestalia Polonica, Seria A, 16:171-200.

Palm, T. 1959: Die Holtz- und Rinden-Käfer der süd- und mittelschwedischen Laubbäume. — Opusc. Entomol. Suppl. 16:1-375.

- 1968. Skalbaggar. Coleoptera. Kortvingar: Fam. Staphylinidae. Underfam. Aleocharinae (Deinopsis-Trichomicra). - Svensk Insektfauna 9, Häfte 5. 112 pp.

Rassi, P., Alanen, A., Kemppainen, E., Vickholm, M. \& Väisänen, R. (eds.). 1985: Uhanalaisten eläinten ja kasvien suojelutoimikunnan mietintö. II. Suomen uhanalaiset eläimet. [Report on the threatened animals and plants in Finland. II. Threatened animals in Finland.] (In Finnish.) Komiteanmietintö 1985:43. 466 pp. Ympäristöministeriö, Helsinki.

Rassi, P., Kaipiainen, H., Mannerkoski, I. \& Ståhls, G. (cds.) 1992: Report on the monitoring of threatened animals and plants in Finland. (In Finnish with English summary.) Komiteanmietintö 1991:30. 328 pp.
Ympäristöministeriö, Helsinki.

Rutanen, I. \& Mannerkoski, I. 1987: Kovakuoriaishavaintoja Mäntsälästä. — Notul. Entomol. 67:213-214.

Saalas, U. 1948: Cis bidentulus Rosenh. (Col., Cisidae) in Ostkarelien gefunden. (In Finnish with German summary.) - Ann. Entomol. Fennici 14:25-26.

Siitonen, J. \& Martikainen, P. 1994: Occurrence of rare and threatened insects living on decaying Populus tremula: a comparison between Finnish and Russian Karelia. Scand. J. For. Res. 9:185-191.

Siitonen, J., Martikainen, P., Kaila, L., Nikula, A. \& Punttila, P. 1995: Kovakuoriaislajiston monimuotoisuus eri tavoin käsitellyillä metsäalueilla Suomessa ja Karjalan tasavallassa. [Biodiversity of Coleoptera in forets areas with different management history in Finland and the Republic of Karelia.] (In Finnish.) - Metsäntutkimuslaitoksen tiedonantoja 564:43-63. Finnish Forest Research Instinute, Vantaa.

Silfverberg, H. 1992: Enumeratio Coleopterorum Fennoscandiae, Daniae et Baltiae. 94 pp. Helsingin Hyönteisvaihtoyhdistys, Helsinki.

Wagner, E. 1955: Aradus ribauti nov. spec. Nouvelle espéce d'Aradidae de France (Hem. Het.). - Vie et Milieu. Bull. labor. Arago 6:5-10.

Vásárhelyi, T. 1978: Contribution to the knowledge of the species Aradus ribauti Wagner, 1955 (Heteroptera: Aradidae). — Folia Entomol. Hungarica 31:199-203. 